\title{
A Study Comparing Antibacterial Activity of Ageratum Conyzoides L. Extract and Piper Betle L. Extract in Gel Dosage Forms Against Staphylococcus Aureus
}

\author{
Arif Budiman $^{1, *}$, Diah Lia Aulifa²
}

\section{Arif Budiman ${ }^{1, *}$, Diah Lia Aulifa ${ }^{2}$}

'Department of Pharmaceutics and Pharmaceutical Technology, Faculty of Pharmacy, Universitas Padjadjaran, Jl. Raya Bandung-Sumedang Km. 21. INDONESIA. ${ }^{2}$ Department of Pharmaceutical Biology, Indonesian School of Pharmacy, Jl. Soekarno Hatta no.354, Bandung, INDONESIA.

\section{Correspondence}

\section{Arif Budiman}

Department of Pharmaceutics and Pharmaceutical Technology, Faculty of Pharmacy, Universitas Padjadjaran, JI. Raya Bandung-Sumedang Km. 21, INDONESIA

E-mail: arif.budiman@unpad.ac.id

History

- Submission Date: 21-02-2020;

- Review completed: 29-02-2020;

- Accepted Date: 05-03-2020.

DOI : 10.5530/pj.2020.12.73

Article Available online http://www.phcogj.com/v12/i3

Copyright

(C) 2020 Phcogj.Com. This is an openaccess article distributed under the terms of the Creative Commons Attribution 4.0 International license.

\begin{abstract}
Background: Microorganisms such as bacteria and viruses often infect humans in their living environments. Staphylococcus aureus (SA) are gram-positive bacteria that are widely used in antibacterial activity experiments and cause infection in the body surface of mammals. Ageratum conyzoides L. (AC) and Piper betle L. (PB)are the natural herbs which have antibacterial activity against SA. Objective: This research was aimed to compare the antibacterial activity of AC with PB extracts in gel dosage form against SA. Methods: The antibacterial activity of both extracts were determined by disc diffusion method and minimum inhibitory concentration ( $\mathrm{MIC})$ were evaluated by the microdilution method. These extracts were formulated into gel dosage form using sodium carboxymethyl cellulose (CMC) with various concentrations and then evaluated for $\mathrm{pH}$, viscosity and antibacterial activity. Results: The results show that both $\mathrm{AC}$ and PB extracts have antibacterial activity against SA with MIC value of $2 \%$ and $5 \%$, respectively. Then, the gel containing $4 \%$ sodium $\mathrm{CMC}$ showed the best physical stability, either containing $\mathrm{AC}$ or PB extract. The gel dosage forms of both extracts did not show any difference in organoleptic properties, $\mathrm{pH}$ and viscosity after 28 days storage. The gel dosage forms of $\mathrm{AC}$ and $\mathrm{PB}$ extracts have antibacterial activity with inhibition zone of $20.3 \mathrm{~mm} \pm 1.3$ $\mathrm{mm}$ and $15.21 \pm 1.3 \mathrm{~mm}$, respectively. Conclusion: ,The antibacterial activity of AC extract was higher compared to that of PB extract in the gel dosage form.
\end{abstract}

Key Words: Ageratum conyzoides L. extract, Piper betle L. extract, Gel, Staphylococcus aureus.

\section{INTRODUCTION}

Microorganisms such as bacteria and viruses often infect humans in their living environments. The antibiotic-resistant microorganisms are on the increase, thereby affecting health-care costs. Many researchers have developed new effective antimicrobial agents that overcome resistance from microorganisms and are cost-effective. ${ }^{1-3}$ Interest in natural products or herbs as an alternative medicine has increased in recent years due to the discovery that they reduce microbial resistance in a cost effective way. In recent years. extracts and essential oils from medicinal plants have became a focus of research especially regarding antimicrobial properties. $^{4}$

One of the natural herbs that have antibacterial activity is Ageratum conyzoides L (AC). The previous study reported that methanol extract and oil from AC inhibits 20 bacteria and four fungi. ${ }^{5}$ The oil from AC has weak activity against Staphylococcus epidermidis, Staphylococcus aureus (SA) and Cladosporium cladosporioides. ${ }^{6}$ AC extract also inhibits the growth of Staphylococcus aureus, Escherichia coli, Pseudomonas aeruginosa and Bacillus subtilis. ${ }^{7}$ The presence of alkaloids, flavonoids, saponins, phenols, and tannins was attributed to the antibacterial activity of $\mathrm{AC}$ extract. $^{8}$
Piper betle L. (PB) extract is also one of the natural herbs which has potential as an antibacterial agent. A previous article reported that Piper betle L. have antibacterial activity against SA, Streptococcus pyogenes, and Escherichia coli. The oil from the leaf of PB showed anti-bacterial activity against Staphylococcus epidermidis, Pseudomonas aeruginosa, Staphylococcus aureus and Escherichia coli. ${ }^{9,10}$ The previous study reported that Piper betle L. contains fatty acids, hydroxy fatty acid esters and hydroxychavicol that exhibits antibacterial activity. Fatty acids can act as anionic surfactants that have selective against Gram-positive organisms by targeting the structure and function of bacterial cell membranes. ${ }^{11}$

SA are gram-positive bacteria that are widely used in antibacterial activity experiments and cause infection in the body surface of mammals. Furthermore, the structure of SA shows a unique cell envelope structure for Gram-positive organisms which is why it was chosen for the study. ${ }^{12}$

\section{MATERIALS AND METHODS}

\section{Materials}

Plant material

$\mathrm{AC}$ and $\mathrm{PB}$ were collected from Research Institute for Medicinal Plants (BALITRO) and were authenticated

Cite this article: Budiman A, Aulifa DL. A Study Comparing Antibacterial Activity of Ageratum Conyzoides L. Extract and Piper Betle L. Extract in Gel Dosage Forms Against Staphylococcus Aureus. Pharmacogn J. 2020;12(3):473-7. 
by the School of Life Sciences and Technology, Bandung Institute of Technology (ITB).

\section{Chemicals}

Mueller-Hinton Agar (MHA) and Mueller-Hinton Broth were purchased from Sigma Aldrich. All other chemicals used in this study were of technical grade.

\section{Extraction}

The AC and $\mathrm{PB}$ were extracted using $70 \%$ ethanol by a maceration method for three $\mathrm{x} 24$ hours at ambient temperature. The $70 \%$ ethanol was removed by a rotary evaporator, IKA company, Germany (IKA RV 10) at $60^{\circ} \mathrm{C}$ to obtain a crude extract of $\mathrm{AC}$ and $\mathrm{PB} .^{13,14}$

\section{Phytochemical screening extract}

The phytochemical screening of AC and PB extract were conducted to determine the presence of secondary metabolites such as flavonoids, alkaloids, tannins, polyphenols, quinones, steroids/triterpenoids, saponins, monoterpenes and sesquiterpenes. ${ }^{15}$

\section{Antibacterial activity of extract}

The antibacterial activity of $\mathrm{AC}$ and $\mathrm{PB}$ extract were conducted using the disc diffusion method. The extracts at various concentrations were dissolved in DMSO $0.01 \%$. Paper discs were soaked in extract solution for 15 minutes and then dried in a laminar air flow for 2 hours. The paper discs containing AC and PB extract, respectively, were placed on the media inoculated SA and then incubated at $37^{\circ} \mathrm{C}$ for 24 hours. ${ }^{16}$

\section{Gel formulation of $A C$ and PB extract}

The gel formulation from $\mathrm{AC}$ and $\mathrm{PB}$ extracts were made according to the formula showed in Table 1. Propylene glycol was mixed with distilled water, and then Sodium carboxymethyl cellulose (CMC) was dispersed into the mixture of Propylene glycol and distilled water. AC and $\mathrm{PB}$ extract, respectively and other components were dissolved in the distilled water and added into the mixture of Propylene glycol and distilled water. The physical stability of the gel formulations from AC and $\mathrm{PB}$ extract were determined including organoleptic properties, $\mathrm{pH}$ and viscosity. ${ }^{17}$

\section{Antibacterial activity of gel from AC and PB extract}

The antibacterial activity of gels from AC and $\mathrm{PB}$ extracts were evaluated with the method of disc diffusion. Paper discs were soaked in the solution of extract for 15 minutes and then dried in a laminar air flow for 2 hours. The paper discs containing gels from $\mathrm{AC}$ and $\mathrm{PB}$ extracts, respectively were placed on MHA media surface inoculated SA and then incubated at $37^{\circ} \mathrm{C}$ for 24 hours. ${ }^{18}$

\section{Statistical analysis}

The result obtained from the experiment were analyzed by the one way analysis of variance (ANOVA) at the level of $(\mathrm{P}<0.05)$ and all data results were presented as a mean of samples \pm standard deviation (SD).

\section{RESULTS AND DISCUSSION}

\section{Phytochemical screening}

Phytochemical screening was conducted to observe the secondary metabolite contained in $\mathrm{AC}$ and $\mathrm{PB}$ extract. The result showed that AC extract contains alkaloids and flavonoids that have antibacterial activity. Flavonoid constituents such as chalcone, aurone, and flavone have aided the antibacterial activity of the plant. ${ }^{19}$

In addition, $\mathrm{PB}$ extract contains sterols, monoterpenes, sesquiterpenes, phenols, flavonoids and tannins base. The Sterols contained in PB extract have great potential as an antibacterial by interacting with the cell walls and membranes of bacteria to change the structure of the ell wall and membrane causing the degradation of bacterial components. Previous study reported that flavonoids and polyphenols contained in the plants have potential as an anti-inflammatory, antiviral, and antioxidant. $^{20}$

\section{Extraction}

Maceration method was used in the extraction process to prevent degradation of antibacterial compounds contained in the $\mathrm{AC}$ and $\mathrm{PB}$ extracts. Ethanol was used as a solvent to optimize the phenol content in the AC and PB extracts. Previous study reported that ethanol extracts have higher phenol levels than water extracts. ${ }^{21}$ The previous article reported that using an organic solvent showed more antibacterial activity compared to the extract using water as a solvent. The similarity of polarization between solvent and bioactive compounds contained in the extract can exhibit high antimicrobial activity. ${ }^{22}$

\section{Antibacterial activity}

The results of antibacterial activity tests for $\mathrm{AC}$ and $\mathrm{PB}$ extract can be seen in the Table 2 .

Table 2 showed that $\mathrm{AC}$ and $\mathrm{PB}$ extract have activity against $\mathrm{S}$. aureus. Previous article reported that Piper betle $\mathrm{L}$. extract contains fatty acid compounds, hydroxy fatty acid ester and hydroxychavicol which have antibacterial activity. Fatty acids at low $\mathrm{pH}$, acts as antibacterial and antifungal by targeting the structure and function of cell walls and

Table 1: Composition of the gel formulation AC and PB extract.

\begin{tabular}{ccccccc}
\hline Materials & \multicolumn{7}{c}{ Formula (\%) } & V & VI \\
\hline & I & II & III & IV & - & - \\
AC extract & 2 & 2 & 2 & - & 5 & 5 \\
PB extract & - & - & - & 5 & 4 & 5 \\
Sodium CMC & 3 & 4 & 5 & 3 & 0.02 & 0.02 \\
Propylparaben & 0.02 & 0.02 & 0.02 & 0.02 & 0.18 & 0.18 \\
Methylparaben & 0.18 & 0.18 & 0.18 & 0.18 & 2.5 & 2.5 \\
Propylene glycol & 2.5 & 2.5 & 2.5 & 2.5 & 2 & 2 \\
Tween 80 & 2 & 2 & 2 & 2 & 100 & 100 \\
Water added & 100 & 100 & 100 & 100 & & \\
\hline
\end{tabular}

Table 2: The results of antibacterial activity tests for AC and PB extract.

\begin{tabular}{ccc}
\hline Materials & MIC & Inhibition zone diameter $(\mathrm{mm})$ \\
\hline Ageratum conyzoides L. extract & $2 \%$ & $12.4 \pm 0.3 \mathrm{~mm}$ \\
Piper betle L. extract. & $5 \%$ & $10.5 \pm 0.8 \mathrm{~mm}$ \\
\hline
\end{tabular}


bacterial membranes. Flavonoid contained in the extract can form complex connections with extracellular and bacterial cell walls. ${ }^{11}$ This data almost similar is even better than the previous studies. Tarun et al reported that the range inhibition zone of PB leaves extract with various solvent were $20.5-38.0 \mathrm{~mm} \cdot{ }^{23}$ While AC leaf extract, durodola reported that 60 fractions of AC leaf extract tested against SA showed antibacterial activity. However, the inhibition zone of antibacterial activity was not reported. ${ }^{24}$

\section{Formulation of gel from $\mathrm{AC}$ and PB extract}

In this study, CMC is an anionic water-soluble natural polymer derivative, which is widely used as a thickening agent in gel dosage forms because of its viscosity-increasing property. ${ }^{25}$ Propylene glycol is a moisturizer and enhancer used to improve drug diffusion through the skin. It also mproves the permeability of compounds contained in the extract in the stratum corneum by changing the solubility parameter of the skin. ${ }^{26}$ Methylparaben and propyl paraben were used as preservatives to prevent the degradation of compounds contained in the extract. ${ }^{27}$

Evaluation of the organoleptic properties of the extracts revealed that the viscosity of the gel increases along with the concentration of sodium CMC and carbomer. Gels from AC and PB extracts were easily spreadable, stable in consistency, odor, and color after 28 days storage.

The $\mathrm{pH}$ measurement of gel dosage form of AC and PB extract after 28 days storage can be seen in Figure 1.

Based on $\mathrm{pH}$ measurements, the $\mathrm{pH}$ of gel dosage form of $\mathrm{AC}$ and $\mathrm{PB}$ extract were in the range of $4.5-6.5$ which still remained within the acceptable $\mathrm{pH}$ for topical dosage forms. The result of statistical analysis showed that there was a significant difference in the $\mathrm{pH}$ of gel from $\mathrm{AC}$ and $\mathrm{PB}$ extract during storage.

The result of viscosity measurements after sterilization can be seen in the following Figure 2.

Based on the measurements, the viscosity of the gel dosage forms of $\mathrm{AC}$ and $\mathrm{PB}$ extracts increased along with the concentration of sodium CMC. This result is similar with previous data reporting on the ability of polymer to increase the viscosity of gels. ${ }^{28}$ The result of statistical analysis showed a significant difference in the viscosity of the gels from $\mathrm{AC}$ and $\mathrm{PB}$ extracts during storage. Generally, the viscosity of gel used to treat skin disorders are expected around 2000-4000 cPs. In this study, the range of gel viscosity containing either AC leaf extract or PB leaf extract was $2000-5000 \mathrm{cPs}$. The gel viscosity $<4000 \mathrm{cps}$ has advantages such as easy to apply and increase penetration of extract into the skin. ${ }^{29}$ The gel containing $4 \%$ sodium CMC showed the best physical stability,

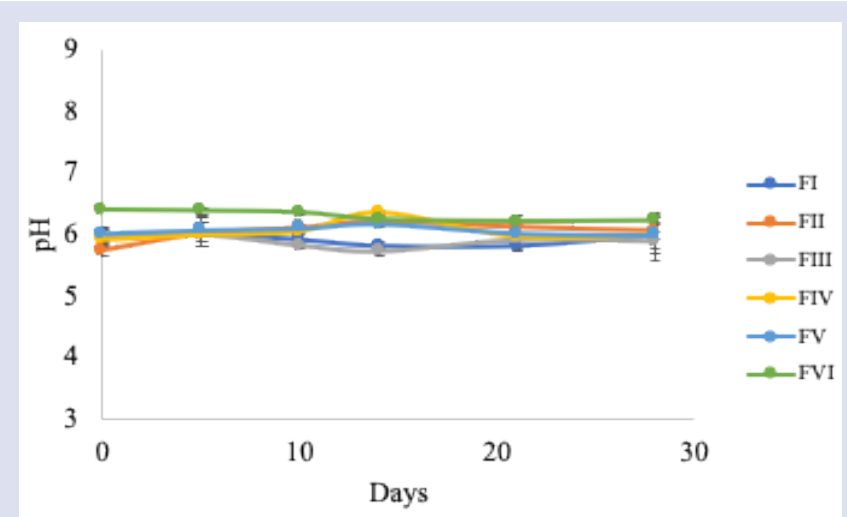

Figure 1: The result of $\mathrm{pH}$ measurement of gel from $\mathrm{AC}$ and $\mathrm{PB}$ extract after 28 days storage (All data results were determined as mean \pm standard deviation; $n=3$ ).

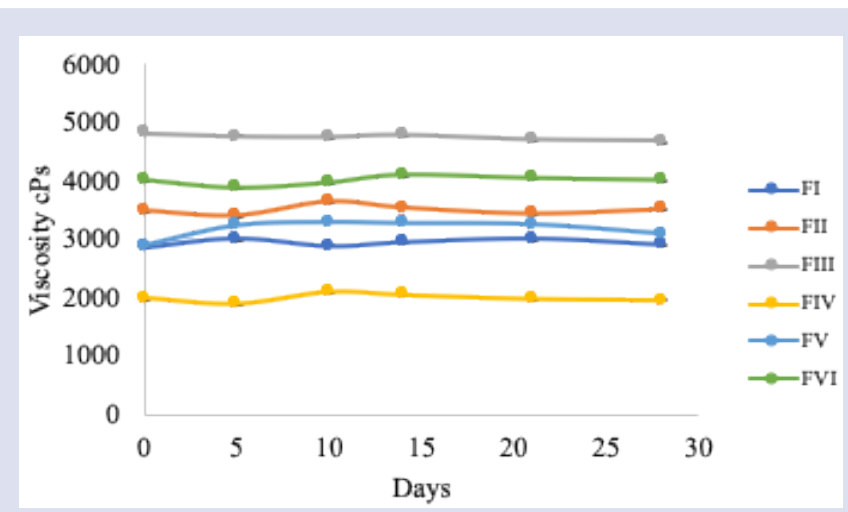

Figure 2: The result of viscosity measurement of gel from AC and PB extract after 28 days storage (All data results were determined as mean \pm standard deviation; $\mathrm{n}=3$ ).

Table 3: The result of antibacterial activity test of gel dosage form from $A C$ and $P B$ extract.

\begin{tabular}{cc}
\hline Materials & Inhibition zone diameter $(\mathrm{mm})$ \\
\hline Control & $0.0 \pm 0.0 \mathrm{~mm}$ \\
Gel without extract & $5.21 \pm 1.7 \mathrm{~mm}$ \\
Gel of AC extract & $20.30 \pm 1.3 \mathrm{~mm}$ \\
Gel of PB extract & $15.21 \pm 1.3 \mathrm{~mm}$ \\
\hline
\end{tabular}

either containing $\mathrm{AC}$ or $\mathrm{PB}$ extract and subsequently would be used in the antimicrobial tests.

The result of antibacterial activity of gel dosage form can be seen in Table 3.

The results showed that both $\mathrm{AC}$ and $\mathrm{PB}$ extracts in gel dosage forms have antibacterial activity. An increase in the diameter of the inhibition zone in the gel dosage form was reported to be due to increasing diffusion of antibacterial compounds. The high water content in a gel dosage form can also increase the penetration of antibacterial compounds through the polar peptidoglycan layer. ${ }^{30}$

\section{CONCLUSION}

The antibacterial activity of the gel dosage form of AC extract (with inhibition zones of $20.3 \mathrm{~mm} \pm 1.3 \mathrm{~mm}$ ) was higher compared to that of $\mathrm{PB}$ extract (with inhibition zones of $15.21 \pm 1.3 \mathrm{~mm}$ ). The gel dosage forms of $\mathrm{AC}$ and $\mathrm{PB}$ extracts have antibacterial activity against $\mathrm{SA}$ with MIC value of $2 \%$ and $5 \%$, respectively. The gel containing $4 \%$ sodium CMC showed the best physical stability, either containing AC extract or PB extract. However, the gel dosage forms of both extracts did not show any difference in organoleptic properties, $\mathrm{pH}$ and viscosity after 28 days storage.

\section{REFERENCES}

1. Jones SA, Bowler PG, Walker M, Parsons D. Controlling wound bioburden with a novel silver-containing Hydrofiber ${ }^{\circledR}$ dressing. Wound Repair Regen 2004;12(3):288-94.

2. Shahverdi AR, Fakhimi A, Shahverdi HR, Minaian S. Synthesis and effect of silver nanoparticles on the antibacterial activity of different antibiotics against Staphylococcus aureus and Escherichia coli. Nanomed- Nanotechnol. 2007;3(2):168-71

3. da Silva Paula MM, Franco CV, Baldin MC, Rodrigues L, BarichelloT, Savi GD, et al. Synthesis, characterization and antibacterial activity studies of poly-\{styreneacrylic acid\} with silver nanoparticles. Mater Sci Eng C. 2009;29(2):647-50

4. Bazargani MM, Rohloff J. Antibiofilm activity of essential oils and plant extracts against Staphylococcus aureus and Escherichia coli biofilms. Food Control. 2016;61:156-64.

5. Okunade AL. Ageratum conyzoides L.(asteraceae). Fitoterapia. 2002;73(1):1-6

6. Martins AP, Salgueiro LR, Gonçalves MJ, Vila R, Cañigueral S, Tomi F, et al. Essential oil composition and antimicrobial activity of Ageratum conyzoides from S. Tomé and Príncipe. J Essent Oil Res. 2005;17(3):239-42. 
7. Ndip RN, Ajonglefac AN, Wirna T, Luma HN, Wirmum C, Efange SM. In-vitro antimicrobial activity of Ageratum conyzoides (Linn) on clinical isolates of Helicobacter pylori. Afr J Pharm Pharmaco. 2009;3(11):585-92.

8. Garg P, Grewal A. In Vitro Antibacterial Activity of Ageratum conyzoides L.(Asteraceae). World J Pharmacy Pharmaceut Sci. 2015;4:893-97.

9. Hoque MM, Rattila S, Shishir MA, Bari ML, InatsuY, Kawamoto S. Antibacterial activity of ethanol extract of betel leaf (Piper betle L.) against some food borne pathogens. Bangladesh J Micro. 2011;28(2):58-63.

10. Akter KN, Karmakar P, Das A, Anonna SN, Shoma SA, Sattar MM. Evaluation of antibacterial and anthelmintic activities with total phenolic contents of Piper betel leaves. Avicenna J Phytomed. 2014;4(5):320.

11. Nalina T, Rahim ZH. The crude aqueous extract of Piper betle $\mathrm{L}$. and its antibacterial effect towards Streptococcus mutans. Am J Biochem Biotech. 2007;3(1):10-5.

12. Kim SH, Lee HS, Ryu DS, Choi SJ, Lee DS. Antibacterial activity of silver nanoparticles against Staphylococcus aureus and Escherichia coli. Korean J Microbiol Biotech. 2011;39(1):77-85.

13. Akhoondinasab MR, Akhoondinasab M, Saberi M. Comparison of healing effect of aloe vera extract and silver sulfadiazine in burn injuries in experimental rat model. World J Plast Surg. 2014;3(1):29-34.

14. Maenthaisong R, Chaiyakunapruk N, Niruntraporn S, Kongkaew C. The efficacy of Aloe vera used for burn wound healing: a systematic review. Burns. 2007;33:713-8

15. Periyanayagam K, Jagadeesan M, Kavimani S, Vetriselvan T. Pharmacognostical and Phyto-physicochemical profile of the leaf of Piper betle L. var Pachaikodi (Piperaceae)—Valuable assessment of its quality. Asian Pac $J$ Trop Biomed. 2012;2:S506-10.

16. Aydin S, Yilmaz O, Gökçe Z. Protective effect of Morus nigra L.(mulberry) fruit extract on the liver fatty acid profile of Wistar rats. Pak J Zool. 2015:47(1):25561.

17. Islam MT, Rodriguez-Hornedo $\mathrm{N}$, Ciotti $\mathrm{S}$, Ackermann C. Rheological characterization of topical carbomer gels neutralized to different $\mathrm{pH}$. Pharm Res. 2004;21(7):1192-9.

18. Nam C, Kim S, Sim Y, Chang I. Anti-acne effects of Oriental herb extracts: a novel screening method to select anti-acne agents. Skin Pharmacol Phys. 2003;16(2):84-90
19. Amadi B, Duru M, Agomuo E. Chemical profiles of leaf, stem, root and flower of Ageratum conyzoides. Asian J Plant Sci Res. 2012;2(4):428-32.

20. Chakraborty D, Shah B. Antimicrobial, antioxidative and antihemolytic activity of Piper betel leaf extracts. Int J Pharm Pharm Sci. 2011;3(3):192-9.

21. Lee YL, Weng CC, Mau JL. Antioxidant properties of ethanolic and hot water extracts from the rhizome of Curcuma aromatica. J Food Biochemi. 2007;31(6):757-71.

22. Nur Syukriah AR, Liza MS, Harisun Y, Fadzillah AAM. Effect of solvent extraction on antioxidant and antibacterial activities from Quercus infectoria (Manjakani). Int Food Res J. 2014;21(3):1031-37.

23. Agarwal T, Singh R, Shukla AD, Waris I, Gujrati A. Comparative analysis of antibacterial activity of four Piper betle varieties. Adv Appl Sc Res. 2012;3:698705 .

24. Durodola JI. Antibacterial property of crude extracts from a herbal wound healing remedy-Ageratum Conyzoides, L. Planta Med. 1977;32(08):388-90.

25. Liu P, Zhai M, Li J, Peng J, Wu J. Radiation preparation and swelling behavior of sodium carboxymethyl cellulose hydrogels. Radiat Phys Chem. 2002;63(36):525-8

26. Jyothi $D$, Koland M. Formulation and evaluation of an herbal anti-inflammatory gel containing Trigonella foenum greacum seed extract. Int J Pharm Pharm Sci. 2016;8:41-4

27. Patil PM, Wankhede SB, Chaudhari PD. Stability-indicating HPTLC method for simultaneous determination of Ketoprofen, Methyl Paraben and Propyl Paraben in gel formulation. J Pharm Res. 2013 ;6(9):945-53.

28. Pednekar A, Dandagi P, Gadad A, Mastiholimath V. Formulation and characterisation of Meloxicam loaded emulgel for topical application. Int J Pharm Pharm Sci. 2015;7:216-22.

29. Kusuma TM, Azalea M, Dianita P, Syifa N. Variations and concentrations effects of gelling agent on the physical properties of hydrocortisone Ge (Pengaruh Variasi Jenis Dan Konsentrasi Gelling Agent Terhadap Sifat Fisik Gel Hidrokortison). Pharmacy Journal of Science and Practice (Jurnal Farmasi Sains dan Praktis). 2018;5(1):44-9.

30. Dermawan AM, Pratiwi L, Kusharyanti I. The effectiveness of anti-acne cream from Impatiens balsamina L. leaves methanol extract. Tradit Med J. 2015;20(3):127-33

\section{GRAPHICAL ABSTRACT}

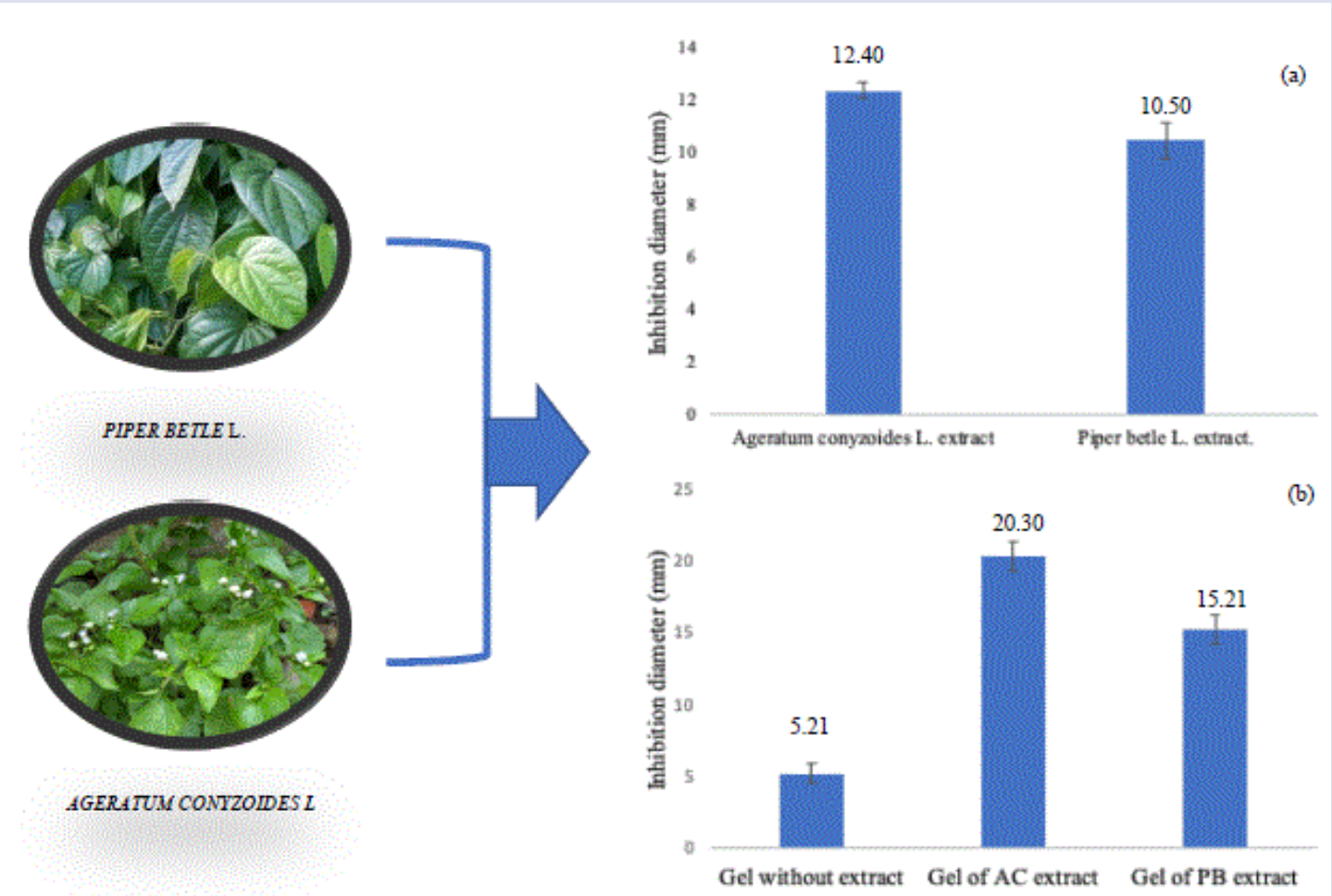




\section{ABOUT AUTHORS}

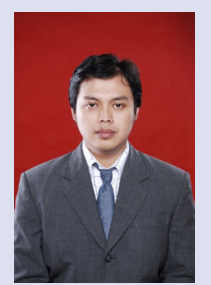

Arif Budiman is a lecturer in Department of Pharmaceutics and Pharmaceutical Technology, Faculty of Pharmacy Universitas Padjadjaran. Develop work in Physical Pharmacy and Pharmaceutical Dosage Forms Development.

Diah Lia Aulifa is a lecturer in Department of Pharmaceutical Biology, Indonesian School of Pharmacy, BandungIndonesia. Develop work in Phytochemistry and Phytotherapy from plants.

Cite this article: Budiman A, Aulifa DL. A Study Comparing Antibacterial Activity of Ageratum Conyzoides L. Extract and Piper Betle L. Extract in Gel Dosage Forms Against Staphylococcus Aureus. Pharmacogn J. 2020;12(3):473-7. 